\title{
Qualitative Data Regarding the Macrophytic Communities Structure in the Wave Breaking Zone at the Romanian Black Sea Littoral
}

\author{
Bogdan-Stefan Negreanu-Pirjol \\ "Ovidius" University of Constanta, Faculty of Pharmacy Constanta, Romania \\ Ticuta Negreanu-Pirjol \\ "Ovidius" University of Constanta, Faculty of Pharmacy, Constanta, Romania \\ Emin Cadar \\ U.M.F. "Carol Davila", Faculty of Pharmacy, Bucharest, Romania \\ Gabriela-Mihaela Paraschiv \\ 3"Ovidius" University of Constanta, Natural and Agriculture Sciences Faculty, \\ Constanta Romania
}

\begin{abstract}
At the Romanian seaside the development of macro-algae mass is reported mainly in summer and is registered especially by the group green macro-algae; thus the largest deposits occur ashore after periods of storm especially, but especially after bottom movement, when a large area of shallow coastline is "shaved" of vegetal carpet. Most macrophyte algae from the Romanian littoral are seasonal species; typical for low temperatures are species of red algae: Bangia, Porphyra and Ectocarpus; species Dasya, Chondria are typical for the summer temperatures and others are frequently met especially in spring - fall; in addition to these, a number of species belonging to the group of green algae. Enteromorpha, Cladophora, are present in all associations succeeding in the year.
\end{abstract}

Keywords: Black Sea Romanian littoral, macroalgal species, hard substratum

\section{Introduction}

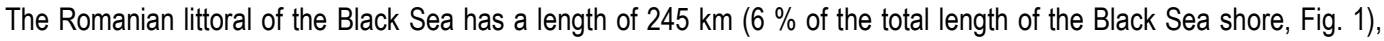
between the flowing mouth of the Chilia Branch, to the border with Ukraine in the north and with Bulgaria in the south.

The Romanian coastal area is divided into two geographical and geomorphic units [3], [13].

The northern unit ( $\mathrm{N}$ ) occupies 2/3 of the total littoral length and stretches between Musura Bay, at the flowing mouth of the Chilia Branch and Cape Singol, including the shore of the Danube Delta Biosphere Reservation (Fig. 1). The area is characterized by sandy beaches with low altitudes and reduced submarine slopes. The beaches are generally wide and made up of sediments which include a large variety of fine sand, silt and sludge fractions, $75 \%$ of this area displaying a relatively high degree of sediment compaction.

It is characterized by the presence of narrow beaches interrupted by limestone platforms that extend into water, and high seawalls (Fig. 1). The superficial sediments include a large variety of mollusk shells and gravel, these beaches being made up of coarse sand with medium granulometry. 
Between the two big geomorphic units of the Romanian littoral, the continental platform extends more to the north (Danube Delta). The terrigenous runoff transported by the Danube causes the sedimentary substrate to be dominated by clay and silt, not favorable for the attachment of macrophytobenthos [2], [3], [7], [8], [9]. Despite this fact, the protection jetties for the harbor and beaches, but most especially the presence of the deep mussel infralittoral biocoenosis (Mytilus galloprovincialis Lamarck, 1819) and its extension (relatively large, from St. George Branch to Vadu and Constanta) determine the development of a harder substrate (shell layer) which permits the installation and development of macrophytobenthos [20], [21], [22], [23], [24], [25 - 28]. This explains the occasional presence of algal deposits at the shore, especially after storms.

The frequency of episodes with macroalgal deposits is higher in the southern sector (and over longer periods of time), a fact explained by the very presence of submerse limestone platforms (Fig. 1).

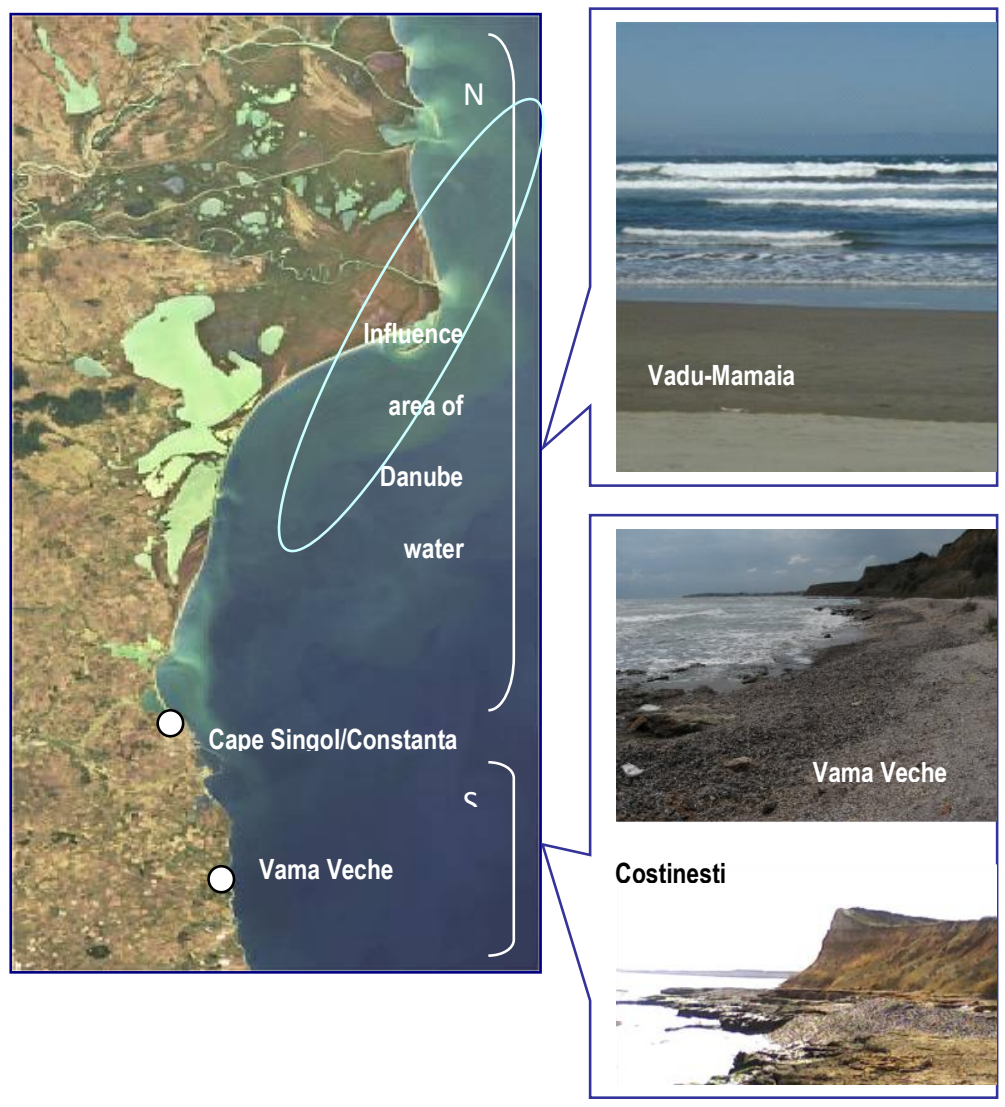

\section{Fig. 1. The South Romanian littoral of the B Sea}

The macrophytobenthos is made up of macroscopic algae (green, brown and red) and phanerogams. It is spread over the north-western continental platform of the Black Sea basin (in littoral zones of low depth) and it can sometimes form important deposits at the shore, especially in the pre-vernal or vernal season or after storms.

The 1980s represent a period of increased eutrophication and pollution, which generated important modifications in the qualitative structure of macrophytobenthos. The effects of these modifications are still felt today [4], [19], 86 macroalgal species were cited in the 1970s-1980s [1], 69 species were cited in the 1980s-1990s and only 55 species after 1990 [20], [21]. This decrease in the number of species (apart from the pollution phenomenon) was attributed to climate changes - 
frost at the Romanian littoral (for unprecedented long periods of time) on the one hand and to the deposits of clay sediments on limestone platforms (fraction mobilized and brought to the sea mass as a result of hydrotechnical constructions in the Harbors of Cape Midia and Agigea South) on the other hand. The sedimentation of clay fractions on the limestone substrate did not permit the attachment of plantules to the substrate [18], [19].

\section{The taxonomic structure of macroalgal communities at the Romanian littoral}

The qualitative analysis of the marine macroalgal communities consists of the elaboration of lists of species, as well as a comparative analysis of communities from different littoral sectors. A previous documentation must be done because there are species with development phase in the prevernal - cold season (February-March), this being the period when they can be encountered at the shore [1], [3], [4], [5], [17], [18].

\section{Green algae - CHLOROPHYTA}

Distributed over the entire length of the Romanian sector, from south of the Danube flowing mouths to the southern extremity of the littoral (Vama Veche). They are more developed in the Cape Singol-Constanta to Vama Veche sector. The mass development of the macroalgal carpet in this sector is explained by the very presence of limestone platforms which cover almost entirely the shallow waters and which represent the ideal substrate for their attachment.

The group includes representatives of Clorophyceae, three orders: Ulvales, Cladophorales and Bryopsidales (Table1); the vegetative apparatus is diverse: lamellate, filamentous, tubular or cladomial [1], [6], [18], [19], [20], [21] (Table.2).

\section{Brown algae - PHEOPHYTA}

Brown algae prefer cold marine waters, developing exuberantly at greater depths than green algae. Representatives from three classes are found at the Romanian littoral: Isogeneratae (with two species of Ectocarpus and one species of Scytosiphon), Heterogenerateae (Punctaria) and Cyclosporeae (with the most representative species at the Romanian littoral from this group, Cystosera barbata (Good et Wood Ag.)

The representatives of the first two classes register reduced biomasses compared to the representatives of green algae, especially in spring and autumn. In the Black Sea, Cystoseira barbata forms a perennial association fixed to the hard substrate, especially in the southern sector of the Romanian littoral. If in the past in was one of the most important associations, covering the infralittoral zone between Agigea-Vama Veche, it is currently much reduced (due to the frost periods in 1975 but also to pollution, increased water turbidity and substrate clogging). The biomass of this alga in deposits at the seashore is relatively reduced, but its importance is given by the fact that its relatively rigid thallus constitutes a substrate for a rich fauna and for epiphytic algae.

\section{Red algae - RHODOPHYTA}

The representatives of this group make up the phytobenthos in the deep zone of the infralittoral. The

algal deposits register an increased biomass compared to brown algae, but reduced in comparison to green algae. Two classes have representatives in the Black Sea:

- Bangiophyceae (with Porphyra leucosticta Thur and Bangia fuscopurpurea Lyngb. Both are cold water species and grow at the end of winter till March without developing significant biomasses, compared to green algae);

- Florideophyceae - with the perennial species, Hildenbrandtia rubra Menegh., (distributed in the shallow zone, attached to rocks or to mollusk shells). The species Corallina officinalis $\mathrm{L}$. (pharmaceutical importance - vermifuge) develops in the shallow infralittoral - permanently covered by water - and shelters a characteristic fauna. It rarely occurs in shore algal deposits. Four species of the genus Phyllophora form "Zernov's field" in the north-western basin of the Black Sea. It registers maximum development at depths of 20-25 m and attaches to sandy substrate with sludgedy matrix. This field suffered a significant reduction but clusters that form associations specific to the invertebrate fauna can still be encountered. The biomass is reduced in the shore deposits. There are four representatives of Ceramiaceae: Callithamnion corymbosum Lyngb. and three species of the genus Ceramium (these develop significant biomasses in the shallow zone - depths 
between 1.5 to $4-5 \mathrm{~m}$, (Fig. 2), in the prevernal and vernal season. One species from Rhodomelaceae - Polysiphonia denudata Grev. encountered in the warm season but without significant biomasses [4], [5], [17], [18].

Table 1. Representatives of Clorophyceae encountered at the Romanian littoral of the Black Sea (according to Sava, 2006 [18], [25 - 28], photo: Sava, Paraschiv)

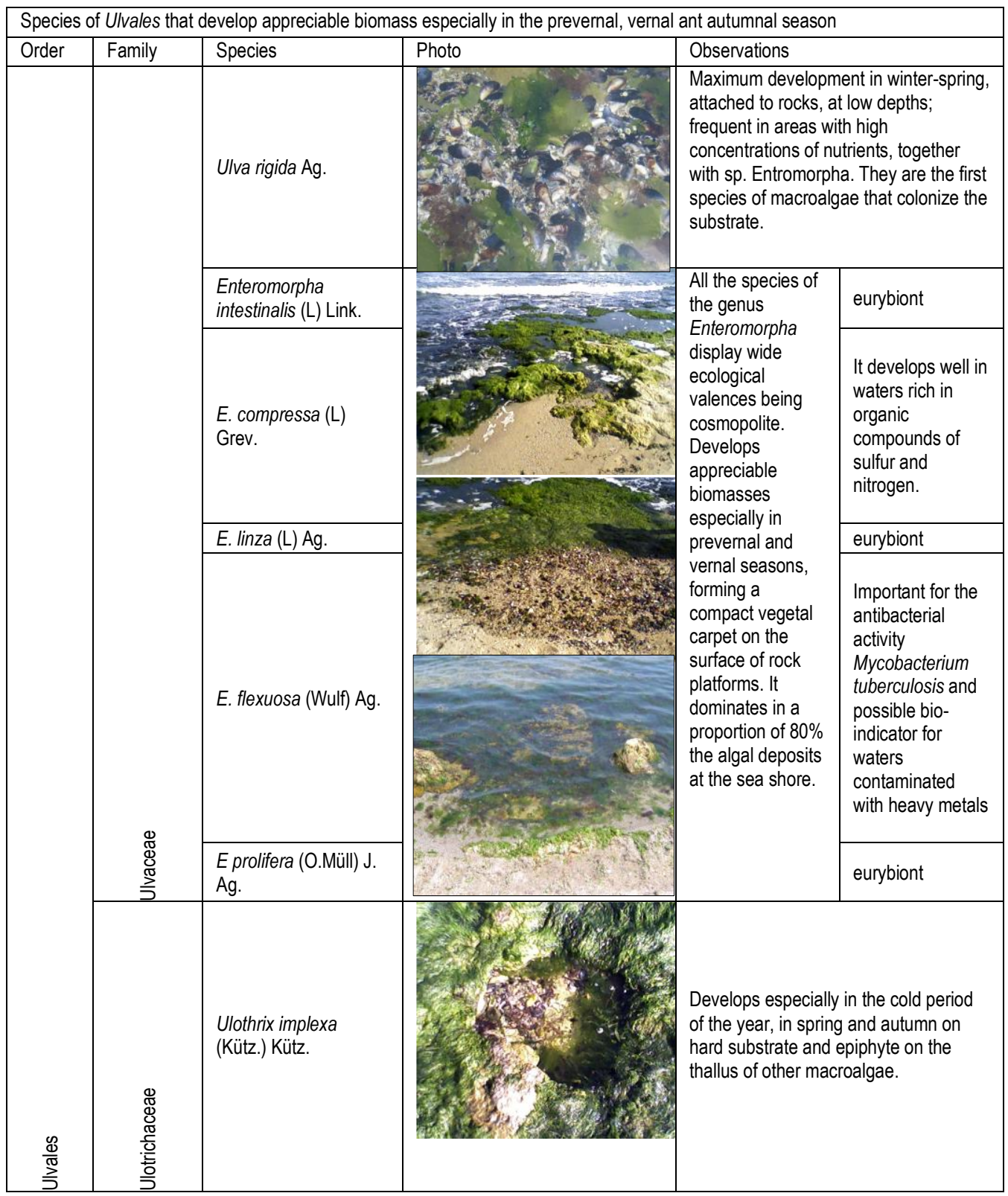


Table 2. Species of Cladophorales that develop appreciable biomass in the prevernal, vernal and autumnal season [25 - 28]

\begin{tabular}{|c|c|c|c|c|}
\hline Order & Family & Species & Observations & \\
\hline \multirow{7}{*}{$\begin{array}{l}\mathscr{0} \\
\frac{d}{\pi} \\
\frac{\pi}{0} \\
\frac{0}{0} \\
\frac{0}{0} \\
\frac{\pi}{0}\end{array}$} & $\begin{array}{l}\mathbb{\Xi} \\
\mathbb{J} \\
\mathbb{0} \\
\stackrel{0}{0} \\
\text { 은 } \\
\frac{0}{0} \\
\text { 인 }\end{array}$ & Urospora penicilliformis (Roth.) Aresh. & $\begin{array}{l}\text { Cold water species } \\
\text { considered arctic relic. } \\
\text { It grows in midlittoral } \\
\text { waters, attached to } \\
\text { rocks but can also } \\
\text { reach greater depths. } \\
\text { It lacks in the } \\
\text { Mediterranean. }\end{array}$ & $\begin{array}{l}\text { Filamentous thallus, } \\
\text { non-ramified that can } \\
\text { reach } 30 \mathrm{~cm} \text { in length }\end{array}$ \\
\hline & \multirow{6}{*}{$\begin{array}{l}\mathbb{8} \\
\mathbb{8} \\
\mathbb{\pi} \\
\overline{0} \\
\frac{0}{0} \\
\frac{0}{0} \\
\frac{\pi}{0}\end{array}$} & Cladophora vagabunda (L) Hoek. & \multirow{5}{*}{\multicolumn{2}{|c|}{$\begin{array}{l}\text { Very abundant at our littoral; a good indicator for } \\
\text { highly eutrophicated waters; wide ecological } \\
\text { valences }\end{array}$}} \\
\hline & & C. sericea (Huds) Kütz. & & \\
\hline & & C. laetevirens (Dillw.) Kütz. & & \\
\hline & & C. albida (Huds) Kütz. & & \\
\hline & & C. dalmatica Kütz. & & \\
\hline & & Chaetomorpha aerea (Dillw.) Kütz. & \multicolumn{2}{|c|}{$\begin{array}{l}\text { Abundant in the warm season, in shallow waters; } \\
\text { it is considered valuable as food in the extreme } \\
\text { east. }\end{array}$} \\
\hline \multirow[b]{2}{*}{$\frac{\mathscr{\infty}}{\frac{\infty}{\pi}}$} & \multirow{2}{*}{ 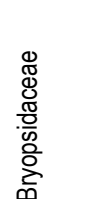 } & Bryopsis plumosa (Huds.) Ag. & \multirow{2}{*}{\multicolumn{2}{|c|}{$\begin{array}{l}\text { It develops well in the warm period of the year, in } \\
\text { eutrophicated waters - even polluted }\end{array}$}} \\
\hline & & B. hypnoides Lamor & & \\
\hline
\end{tabular}

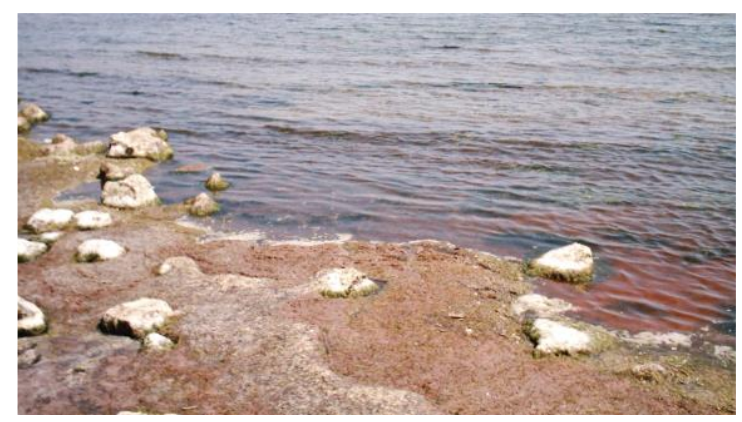

Fig. 2. Algal deposit at the sea shore made up of species from the genus Ceramium and depigmented green algae in advanced decomposition state (Eforie Sud, Photo: Paraschiv)

\section{Materials and Methods}

\section{Collection and processing of samples of macrophytic algae}

\section{Qualitative analysis}

It involves the collection of samples from different places along the transect line without applying the sampling method (Fig.

3). The result of this type of analysis is represented by the list of species. 


\section{Sample collection for qualitative determinations}

Observations and collection of algae for qualitative determination was made monthly, especially after storm periods, to identify the dominant perennial and seasonal species, and to capture the different stages of the development cycle. Fresh algal samples were taken in the laboratory, washed of the associated fauna and sorted in the main groups; the sampling is done so that the estimation of the abundance can be done (after density and biomass); for this purpose, a classical procedure was pursued, but unanimously supported by specialists in the world community, that of sampling the "square sample".

Samples are obtained by integral collecting of plant biomass by scraping the substrate corresponding to a square sample; for each sample at least one replicate was taken; samples are stored in the chest freezer and will be processed in the laboratory. Photographs in the field, before taking samples, will complete the picture of the structure of macro-algal associations from the southern part of the Romanian coast.

In this case, the study objective was to establish a list of species in a given region. The study of biodiversity is complex and long, its purpose being more than just the publication of lists of species valid at one moment, but also the appreciation of the way in which these lists change in time and space, as well as the reasons for these changes, which can be due to natural variability or the impact of biotic and abiotic factors.

In order to obtain this kind of long-term results and for their comparison in time and space, it is necessary to standardize them and maintain them at the same level of precision in sample collection, as well as their processing and analysis. These objectives are difficult to reach for practical reasons, especially in the case of macrophytes.

Algae collection for qualitative determinations takes place monthly or at least once every other month in order to detect not only the perennial but also the seasonal species, as well as for the determination of stages in the development cycle. Also, it is recommended to collect whole samples, both with the fixing portions (rhizoids, disks or cramps) and the apical parts of the thallus, all structures being necessary for the correct identification of species.

Algal samples are brought fresh to the laboratory, washed from the associated fauna and sorted on main groups. The fresh material is determined macroscopically and microscopically, using field guides or specialized papers: Ulvales (Chlorophyta) from URSS Seas (Vinogradova, 1974); A critical survey of European Taxa in Ulvales (Bliding, 1963); Revision of European species of Cladophora (van Hoek, 1963); Sur le Ceramium de la Mer Noire (Celan şi Şerbănescu, 1959); Algology Book vol II, vol III (1977, 1979); Wold Life Diversity-llustrated Book of Romanian Flora and Fauna, vol I -Marine Environmental (1995); Guides des algues des mers d'Europe (Bouduresque, 1992).

\section{Quantitative analysis}

This type of analysis involves the collection of biological samples usable for an estimation of abundance (according to density and biomass) [8]. For this purpose, a classical method is used as it is unanimously accepted by specialists and known as the sampling by means of the "sample square."

\section{Establishing transects (Fig. 3.a).}

Transects that conform to certain conditions must be chosen in order to collect samples of macrophytic algae:

- To be accessible in different climatic conditions,

- $\quad$ To be easy to locate but to maintain the collection conditions,

- $\quad$ To tolerate repeated collections (samples), at different distances from the shoreline. 


\section{Substrate}

In the distribution of flora and algal vegetation, the nature and aspect of the substrate are very important. Apart from the rocky substrate (Fig. 3.b), limestone platforms, protection jetties), two other factors are also important: the substrate represented by mollusk shells and the thallus of certain algae, for fauna.

\section{Materials and equipment}

Simple and accessible equipment is needed for the collection of samples: knife, plastic bags, cloth sacks, plastic dishes, tracing paper, pencil, refrigerating box. The samples are obtained by the total collection/scraping from the substrate of a vegetal biomass corresponding to a sample. At least one replicate will be taken for each collection. The samples are kept in the refrigerating box and processed in the laboratory.

\section{Sample collection for quantitative determinations}

The quantitative estimations are important for the understanding of the structure and functioning of a population, for the analysis of the biochemical compounds, as well as for the estimation of current deposits, especially in the case of species valuable from the economical point of view.

The quantitative collection of macrophytic algae is realized using the square method, by means of frames of proper sizes, which are established according to the characteristics of the respective population, as well as to the type of substrate.

In concrete conditions regarding the type of macrophytic algal vegetation at our littoral, as well as the substrate it prefers, wooden frames $(10 / 10 \mathrm{~cm})$ are used for quantitative collection (Fig. 3).

All the algae from this surface are collected, each sample being introduced into a plastic bag and labeled with the date, place and depth of collection. Three replicates are usually collected from each depth.

The fresh samples brought to the laboratory are washed from the associated fauna, sorted on main groups (green, red and brown algae). Then, the species are separated in each group after their prior identification.

In order to obtain the dry biomass values, the samples are dried at $105^{\circ} \mathrm{C}$ in the drying oven for 24 hours. The biomass is calculated for each species and the final value is represented by the average of each species collected in the three samples from each depth, then multiplied by 100 and expressed in $\mathrm{g}^{*} \mathrm{~m}^{-2}$.

The value of abundance according to the dry biomass (e.g. for Cladophora vagabunda), collected from a depth of $1 \mathrm{~m}$ : $\mathrm{A}_{1}$ - value of dry biomass from the first replicate; $A_{2}$ - value of dry biomass from the second replicate; $A_{3}$-value of dry biomass from the third replicate; $B \mathrm{~g} / \mathrm{m}^{2}$ (Cladophora biomass at $\left.1 \mathrm{~m}\right)=\left(A_{1}+A_{2}+A_{3}\right) \times 100$

At the end of sample processing and identification of species, the individuals in each species are counted and thus we obtain the abundance on sample surface. The arithmetic mean is realized depending on replicates and its value is extrapolated to square meter (surface unit) and represents abundance according to density (expressed in number of individuals per species $\left.{ }^{*} \mathrm{~m}^{-2}\right)$.

\section{Results and Discussions}

Macrophytes recorded mass development during periods of optimal thermal and nutrients regime, as follows: species of clorophyte group (Table 3): Urospora penicilliformis, red algae species, Bangia fuscopurpurea, Porphyra leucosticta, Ectocarpus siliculosus are frequently met in February and May, while species Dasya, Chondria appear during summer; cosmopolite species belonging to genus Enteromorpha (E. intestinalis, E. compressa, E. linza, E. flexuosa, E. prolifera) Ulva rigida, Ceramium (C. elegans, $C$. diaphanum) are present in all the associations follow one another during the year. Perennial algae: Cystoseira barbata and $\mathrm{Cy}$. bosphorica from the shallow rocky littoral areas and Phyllophora nervosa, $\mathrm{Ph}$. brodiaei from greater depths of circa littoral, but until $50 \mathrm{~m}$ (almost 50 years ago a wide field of about $11000 \mathrm{~km}^{2}$, in the NW 
part of the sea was described as a true red "plain" formed by species of genus Phyllophora - with a biomass over 5,6 million tone; this representing one of the basic biological characteristics of the Black Sea [17].

Observations and studies that we have done over several years enabled us to identify the two summer periods in which large amounts of macro-algae are detached from the substrate and bonded to the shore (especially in the group of green algae-Chlorophyta), in June - August .

In addition to natural factors such as prolonged periods of freezing from the Romanian seaside in the years ' $70-{ }^{-} 80$, the emergence of high intensity storms, the anthropogenic factors have had an important contribution; studies in recent years have shown a significant decrease in the number of species of algae covering the shallow littoral south of Constanta (Table 4, [18]), and this was made on behalf of human impact stemming mainly from the work of the Port of Constanta South Agigea (large amounts of fine clay sediments reached the water through port works and hydro technical works, determining decrease of transparency and change of shallow bottom waters because the sediments that were deposited on hard substrate created a mobile substrate and prevented macro-algae deposition).

a.

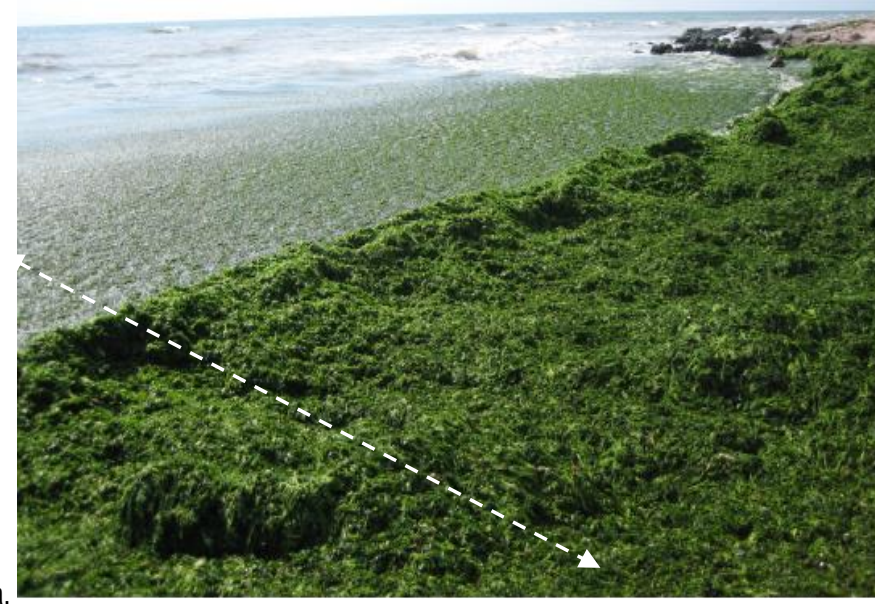

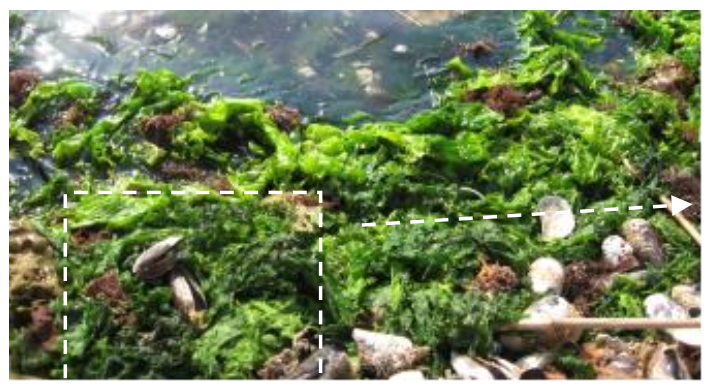

b.

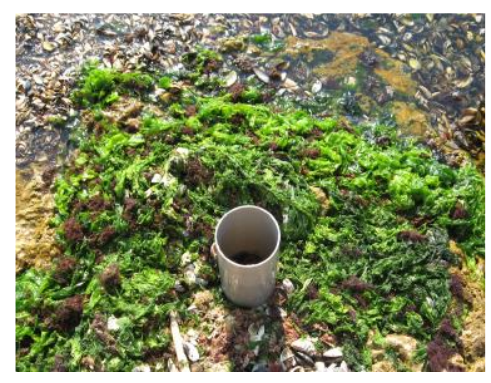

c.

\section{Fig. 3. Sample}

collection: the sample square" for qualitative and quantitative determinations of the macroalgal flora: a. the choice of transects perpendicular to the shore line; b. the "sample square" method; c. sampling by corer for quantitative determinations in the depth of the column with algal substrate and fauna associated to this substrate (Photo: a. Vama Veche - 2 Mai; b. Vama Veche and Mangalia; Paraschiv, Sava, Negreanu), [25 - 28] 
All shoreline protection works (against beaches erosion and for tourist activities) caused changes in the movement of littoral currents, being created areas with low dynamic of water bodies and thus eliminated rheophile/oxygenophile species in these areas.

Today only about one third of the total number of macro-algae species is encountered, compared to species cited 50 years ago; this has allowed the mass development of cosmopolitan, opportunistic, short life cycle species, especially belonging to the group Chlorophyta (green macro-algae); the most significant decrease is recorded for red ( 31 species in this group no longer being found on the Romanian seaside in the past 50 years) and brown macro-algae species ( 9 species). An important ecological niche for the development of marine benthos on hard substrate of the littoral part from the south of Constanta was represented by the "field of Cystoseira barbata"; currently in this field have left only small "oasis" with a much reduced surface [Sava et. al., (2007)].

\section{Table 3. The most abundant algae species identified in algae agglomerations on the shore}

(after Sava, [18], [25 - 28])

\begin{tabular}{|l|l|l|}
\hline $\begin{array}{l}\text { Nr. } \\
\text { crt. }\end{array}$ & Taxonomic group & Species \\
\hline CHLOROPHYCEAE & Ulva rigida (lactuca) (L.) \\
\hline 1 & Ulvales & Enteromorpha intestinalis (L.) Link. \\
\hline 2 & & E. compresa (L.) Grev. \\
\hline 3 & & E. linza (L.) Ag. \\
\hline 4 & & E. flexuosa (Wulf.) Ag. \\
\hline 5 & & E. prolifera (O.Múll) J. Ag \\
\hline 6 & & Urospora penicilliformis (Roth.) Aresh \\
\hline 7 & Cladophorales & Cladophora vagabunda (L.) Hoek. \\
\hline 8 & & C. sericea (Huds.) Kütz. \\
\hline 9 & & C. albida (Huds.) Kütz. \\
\hline 10 & \multicolumn{2}{|l|}{ Bryopsis plumosa (Huds.) Ag. } \\
\hline 11. & Bryopsidales & B. hypnoides Lamour \\
\hline 12 & \multicolumn{2}{|l|}{} \\
\hline ISOGENERATAE - PHAEOPHYTA \\
\hline 13 & Ectocarpales & Ectocarpus siliculosus (Dillw.) Lyngb. \\
\hline CYCLOSPOREAE - PHAEOPHYTA \\
\hline 14 & Fucales & Cystoseira barbata (Good et Wood) Ag. \\
\hline FLORIDEOPHYCEAE-RHODOPHYTA \\
\hline 15 & Ceramiales & Callithamnion corymbosum (Smith.) Lyngb. \\
\hline 16 & \multicolumn{2}{|l|}{ Ceramium rubrum (Huds) Ag. } \\
\hline 17 & Ceramium elegans (Roth.) Ducl. \\
\hline
\end{tabular}

Table 4. The decrease of the number of macrophyte algae species during 1977-2007

(data after Sava [19], [18], [25 - 28])

\begin{tabular}{|l|l|l|l|}
\hline \multirow{3}{*}{ Phyllum } & After data: & \multicolumn{3}{|l|}{} \\
\cline { 2 - 4 } & Bavaru & Vasiliu & Sava \\
& 1977 & $1980-1995$ & 2007 \\
\hline Chlorophyta & 31 & 22 & 16 \\
\hline Phaeophyta & 14 & 9 & 5 \\
\hline Rhodophyta & 41 & 24 & 10 \\
\hline Total & 86 & 55 & 30 \\
\hline
\end{tabular}

\section{Conclusion}

The most important features of macro-algal communities in the southern Romanian Black Sea Coast are: 
- $\quad$ reduced number of species in groups of red and brown macro-algae;

- $\quad$ proliferation of opportunistic species of green macro-algae group, with short life cycle and which can develop impressive biomass in a relatively short time; these few species occupies $80 \%$ area of shallow sea bottom;

- $\quad$ reduce the area occupied by perennial macro-algae, Cystoseira and Phyllophora.

- $\quad$ To improve the existing situation is necessary to popularize the importance of species (rare species and especially of perennial ones) on one hand, and to recover large amounts of macro-algae biomass produced during summer on the other hand.

\section{Acknowledgments}

Scientific investigations were funded by Norway Grants Program - Innovation Norway, "Norwegian Cooperation

Programmes for Economic Growth and Sustainable Development in Bulgaria and Romania", Project no. KNRIN 2008/115241.

\section{References}

[1] Bavaru, A., Contribution of algal association study from rocky substratum of Black Sea coast, PhD Thesis, Ed. Bucuresti University, 1977, 195 pp.

[2] Băcescu, M.C., Substratum; Marine Ecology, vol. I, part. 3, London, 1972, 1291-1314 pp.

[3] Băcescu, M., Müller, G.I., Gomoiu M.T., Cercetari de ecologie bentală în Marea Neagră. Analiza cantitativă, calitativă şi comparată a faunei bentale pontice. Ecologie marină 1971, 4, 1-357 pp.

[4] Bologa, A.S., Destruction of marine biodiversity - a case study of the Black Sea. IOI-Pacem in Maribus XXVII Conference, Proceedings, 2001, 249-254 pp.

[5] Bologa, A.S., Sava, D, Progressive decline and present tend of Romanian Black Sea macroalgal flora - Marine Research, 2006, 36: 31-60 pp.

[6] Celan, M, Şerbănescu, G, Sur les Ceramium de la mer Noire- Lucr. Ser. St. Stat. Zool. Mar. „Prof. I. Borcea”, Agigea, 1959, 531-56 pp.

[7] Dumitrache, C., Present state of the zoobenthos from the Romanian Black Sea continental shelf. Cercetari marine Recherches marines, IRCM Constanta, 1996-1997, 29-30: 141-151 pp.

[8] Godeanu, S., Botnariuc, N., Petran, A., Caracterizarea ecologica generală a ecosistemelor acvatice; Pontus Euxinus, Cercetari si studii, II, 1982, 258-270 pp.

[9] Godeanu, S., Paraschiv, G.M., Compendiu de Ecologie Aplicată/Caiet de lucrări practice, 198 p., Ed. Bucura Mond, 2005, $181 \mathrm{pp}$.

[10] Gomoiu, M.-T., Marine Eutrofication Syndrome in the Northwestern Part of the Black Sea. Science of the Total Environmental, Supp. Else. Scie. Publ. B. V., Amsterdam, 1978, 683-692 pp.

$[11]^{* * *}$ Some problems concerning actual ecological changes in the Black Sea. Cercetari Marine - Recherches marines, IRCM Constanta, 1981, 14: 109-127 pp.

[12] Kinne, O., Marine Ecology: Zonation and Organismic Assemblages; In. Vol. V, Part 1; Ed. John Wiley \&Sons-New York, 1982, 267-508 pp.

[13] Panin, N., On the Geomorphological and Geological Evolution of the River Danube - Black Sea Interaction Zone; GeoEcoMarina 2: Fluvial-Marine Interactions, Bucuresti, 1997, 31-40 pp. 
[17] Sava, D., Pollution Ecological Assessment of Macrophytic Cenosis From Rocky Black Sea Coast, PhD Thesis, "Ovidius" University Constanţa, 2002, 233 pp.

[18] ${ }^{* * * M a c r o f i t i c ~ a l g a l ~ f r o m ~ R o m a n i a n ~ B l a c k ~ S e a, ~ E d . ~ E x ~ P o n t o, ~ „ O v i d i u s ” ~ U n i v e r s i t y ~ P r e s s, ~ C o n s t a n t a, ~ 2006, ~} 147$ pp.

[19] Sava, D. Samargiu, M.D., Paraschiv, G.M., Macroalgal Flora from the Romanian Black Sea Coast - Diversity, Ecology, present tend; The $8^{\text {th }}$ National Conference of Environmental Protection and $5^{\text {th }}$ National Conference of Ecosangenesis - May 2007: 100-104.

[20] Vasiliu, F., Macrophytic Algal Production from Romanian Black Sea Coast; PhD Thesis, Bucuresti University, 1984, $210 \mathrm{pp}$.

[21] ${ }^{* * *}$ Ecological Consideration of Macrophytic Species List from Romanian Black Sea Coast; Naturalia - Piteşti, St. cerc. II-III, 1996, 432-444 pp.

[22] Tigănuş, V., Modifications dans la structure de la biocenose des sables a Corbula mediterranea (Costa) du littoral roumain. Rapp.Comm.int.mer Medit., 1982b, 28: 205-206 pp.

[23] Tigănuş, V., Evolution des peuplements macrobenthiques du substrat sablonneux sur le littoral roumain. Rapp.Comm.int.mer Medit., 1990, 32, 1:22.

[24] Tigănuş, V., Dumitrache C., Sur la diversite actuelle de la macrofaune benthique du littoral roumain. Rapp. Comm. int. mer Medit., 1995, 34: 45.

[25] Negreanu-Pîrjol, T., Negreanu-Pîrjol, B., Năstac, M., Paraschiv, G.M., Qualitative data about shallow waters macroalgal resources from South Romanian Black Sea Coast", International Conference on the Conservation and Sustainable Use of Wild Plant Diversity - CSUWPD 2010, 4-8 May 2010, Kolympari, Chania, Crete, Greece, Section: Wild Plant in Scientific Research and Development (SRD), Abstracts, p. 55.

[26] Negreanu-Pîrjol, B., Negreanu-Pirjol, T., Paraschiv, G., Bratu, M., Sirbu, R., Roncea, F., Meghea, A., Physicalchemical characterization of some green and red macrophyte algae from Romanian Black Sea littoral, Scientific Study \& Research-Chemistry \& Chemical Engineering, Biotechnology, Food industry, 2011, 12 (2), pp. $173-184$.

[27] Paraschiv, G.M., Negreanu-Pirjol, T., Negreanu-Pirjol, B., Sirbu, R., Study of the invertebrates fauna associated of the macroalgal biomass from the Romanian Black Sea Coast, 12 $12^{\text {th }}$ International Multidisciplinary Scientific GeoConference „Modern Management of Mine Production, Geology and Environmental Protection” - SGEM 2012, 17 - 23 June 2012, Albena, Bulgaria, Conference Proceedings, Volume V, Section „Ecology and Environmental protection", pp. 801-808.

[28] Paraschiv, G.M., Negreanu-Pîrjol, B.-Ş., Arpenti, M., Jurja, S., Mireşan, H., Negreanu-Pîrjol, T., Evaluation of physicchemical and biological conditions from the psammic habitats that are populated by interstitial cnidarian species (cnidaria-hydrozoa) from Vama Veche, Romanian Black Sea Coast, 14 ${ }^{\text {th }}$ International Multidisciplinary Scientific GeoConferences „Surveying Geology \& mining Ecology Management - SGEM 2014”, 17 - 26 June 2014, Albena, Bulgaria, Conference Proceedings, Volume II, Section: „Water Resources, Forest, Marine and Ocean Ecosystems”, pp. 601 - 606 . 